\title{
НОВЫЕ КНИГИ
}

Бы ко в Ю. С., Теория разборчивости речи и повышение эффективности радиотелефонной связи, Госэнергоиздат, 6 п. л., 10000 экз., ц. 9 руб., вып. II кв. 1959.

Рассматриваются преимущества пользования критерием разборчивости речи вместо отношения сигнал/помеха при проектировании линий связи. Излагаются основные теории разборчивости и методика расчета и экспериментального определения разборчивости при помехах и шумах.

Книга рассчитана на инженерно-технических работников.

Г е й ц е, Введение в электровакуумную технику (пер. с нем.), Госэнергоиздат, 30 п. л., 15000 экз., ц. 16 руб., вып. II кв. 1959.

Рассматриваются основы техники электровакуума, производственная и лабораторная аппаратура и оборудование, технология электровакуумных приборов, электровакуумные материалы.

Книга предназначена для научных работников, инженеров и студентов вузов.

Г о в орков В. А., Электрические и магнитные поля (изд. 2-е), Госэнергонздат, 23 п. л., 10000 экз.; ц. 13 руб., вып. II кв. 1959.

Излагается теория электромагнитного поля применительно к целям практического расчета электромагнитных полей, встречающихся в радиотехнике, технике связи, электроэнергетике, аппаратуре автоматики и телемеханики. Излагаются методы приближенных расчетов полей (в частности, метод сеток).

Книга предназначена для студентов и аспирантов вузов, инженеров и научных работников.

Г у д э Г., Промышленная электроника (пер. с франц. под ред. Қ. М. Шифрина), Госэнергонздат, 37 п. л., 25000 экз., ц. 20 руб., вып. І кв. 1959.

Рассматриваются принципы устройства и действия электронных приборов и современные приложения электроники в науке и технике.

Книга предназначена для"научных работников, инженеров и студентов вузов.

Н а д е н е н к О С. И., Антенны, Связьиздат, 33 п. л., 25000 экз., ц. 13 руб.

Рассматривается теория измерения и приема радиоволн, описываются антенны и линин передачи электромагнитной энергии, приводятся параметры, методы расчета и указание по эксплуатации антенно-фидерных сооружений.

Книга рекомендуется в качестве учебного пособия для студентов вузов.

U те й н Б. Б., Ч е р я к Н. А., Однополосная модуляция при помощи фазосдвигающих систем, Связьиздат, 10 п. Л., 10000 экз., ц. 6 руб. 50 коп.

Рассматриваются вопросы анализа, методики построения и использование многофазиого преобразования частот (выделение одной боковой полосы посредством многофазной модуляции, выделение одной боковой полосы в системах радиосвязи и применение принципа однополосного преобразования частот в технике проводной связи и в радиовещании).

Ш ерм ан Я. Д., Радиоволны и объемные резонаторы, Связьиздат, 24 п. л., 10000 эКз., ц. 14 руб.

Нзлагается теория физических процессов в волноводах и объемных резонаторах, рассматриватотся возбуждение волноводов и неоднородности в волноводах, замедляюице и анизотропные волноводные системы. 